\title{
THE METHODOLOGIES FOR INVENTORY ANALYSIS IN THE LOGISTIC CHAIN OF AN ENTERPRISE
}

\author{
Andrea Rosová \\ Technical University of Kosice, Faculty of Mining, Ecology, Process Control and Geotechnology, Letna 9, 04200 \\ Kosice, Slovak Republic, andrea.rosova @ tuke.sk \\ Peter Kačmáry \\ Technical University of Kosice, Faculty of Mining, Ecology, Process Control and Geotechnology, Letna 9, 04200 \\ Kosice, Slovak Republic, peter.kacmary@tuke.sk \\ Jana Fabiánová \\ Technical University of Kosice, Faculty of Mining, Ecology, Process Control and Geotechnology, Letna 9, 04200 \\ Kosice, Slovak Republic, jana.fabianova @ tuke.sk
}

Keywords: inventories, materials, consumption, resources, material substitution

Abstract: Stocks in the process of extended reproduction in a production and in a circulation are items (capital goods and consumer goods), which are stored for later consumption. Their need is caused by a discrepancy between cycles of supplies and consumption of individual stocks in a production, by a specific seasonality, transportation of certain amounts which are not in conformity with current consumption.

\section{Introduction}

Inventories are material assets in enterprises' premises being part of non-current assets used on a short-term basis. The role of inventories is to ensure continuous and economic production connected with a high level of capacity yield and to hide non-synchronous capacities and processes prone to failures. Inventories can be of positive influence when solving time and product mix-related nonconformities resulting from different unexpected deviations and outages of material production or delivery. In last few years, the way inventories are looked at has changed substantially. They are no longer the first alternative to use when trying to ensure the flexibility in production. Currently, they are seen as the last resort for enterprises [1].

The negative side of inventories is that there are significant capital funds tied up in therm. Moreover, inventories cause further costs and expenses related to their maintenance and there is a risk of their deterioration, obsolescence or unsaleability related to space, capacity or demand when trying to achieve optimum batches and dampen down. From the logistics point of view, inventories have been treated with a significant difference. They are no longer considered the first alternative how to ensure flexible and reliable chain functioning. Currently, they are the last resort or, in other words, emergency solution. From the perspective of logistics, inventories are no longer corporate assets. For logistics they are liabilities.

\section{The methodologies for inventory analysis in the logistic chain of an enterprise}

Inventories are material assets in enterprises' premises being part of non-current assets used on a shortterm basis.

The role of inventories is to ensure continuous and economic production connected with a high level of capacity yield and to hide non-synchronous capacities and processes prone to failures. Inventories can be of positive influence when solving time and product mix-related nonconformities resulting from different unexpected deviations and outages of material production or delivery.

In last few years, the way inventories are looked at has changed substantially. They are no longer the first alternative to use when trying to ensure the flexibility in production. Currently, they are seen as the last resort for enterprises [7].

The negative side of inventories is that there are significant capital funds tied up in therm. Moreover, inventories cause further costs and expenses related to their maintenance and there is a risk of their deterioration, obsolescence or unsaleability related to space, capacity or demand when trying to achieve optimum batches and dampen down. From the logistics point of view, inventories have been treated with a significant difference. They are no longer considered the first alternative how to ensure flexible and reliable chain functioning. Currently, they are the last resort or, in other words, emergency solution. From the perspective of logistics, inventories are no longer corporate assets. For logistics they are liabilities. 
2.1 Method of Determining Corporate Stock Levels in a Corporate Logistic Chain

Inventory is any available economic source that is not fully used in the given time interval and its amount is determined so as to able to cover future demands in the best way possible from economic point of view.

Inventories as an item subject to management characterise the active part of corporate capital, which is fully transferred in the manufacturing process of each enterprise and, at the same time, becomes part of corporate performance (product).

Inventories are a first-line cost factor [3].

\subsubsection{Standardising Material Stock and Its Consumption}

Stock standard - relative values:

$$
Z_{r}=\frac{-D C}{2}+Z_{i} \cdot \check{C}
$$

Stock standard - absolute values:

$$
Z_{a}=Z_{r} \cdot \mathrm{S}_{\mathrm{d}}
$$

where:

$Z_{r}=$ Material stock standard in its relative time values;

$D C=$ Average cycle of given material deliveries (in days);

$Z_{i} \cdot \check{C}=$ Material safety stock expressed in time units;

$Z_{a}=$ Material stock standard in its absolute values;

$S_{d}=$ Average daily consumption of the material given; [3]

Then, the turn-round time of a particular item will be calculated as follows:

$$
O_{d}=\frac{-Z_{a}}{S_{d}}
$$

and the number of given material turns for a certain period of time will be:

$$
O_{p}=\frac{S_{c}}{Z_{a}}
$$

where:

$S_{c}=$ Total consumption of a given material item for time periods monitored;

\subsubsection{Utilisation of Material Sources}

The index of average consumption dynamics per one type of material sources for different types of production is expressed by the following formula:

$$
I_{d s}=\frac{\sum m_{1} q_{1}}{\sum m_{0} q_{1}}
$$

where:

$I_{d s}=$ Index of consumption dynamics;

$m_{1} m_{0}=$ Material consumption calculated per unit of production in the monitored and preceding period; $q_{1}=$ Volume of all kinds of products manufactured from the material given;

The index of average consumption dynamics per several types of material per unit of production consisting of several types of products is expressed by the following formula [3]:

$$
I_{d s}=\frac{\sum m_{1} c_{0} q_{1}}{\sum m_{0} c_{0} q_{1}}
$$

where:

$I_{d s}=$ Index of consumption dynamics,

$c_{0}=$ Production or wholesale price of materials;

\subsubsection{Material Consumption}

Material consumption $(S)$ needed in order to manufacture a product consists of the net consumption of weight or volume of a finished product $\left(S_{c}\right)$, waste $\left(O_{d}\right)$ and non-returnable loss $\left(S_{n}\right)$. In other words [3]:

$$
S=S_{c}+O_{d}+S_{n}
$$

The degree of useful application of material is expressed in percentage, i.e. as the utilisation factor $(K v)$. It is used to calculate the above for single product as well as for all materials used.

$K v=\frac{S_{c}}{S}, K v=\frac{S_{c}}{S_{c}+O_{d}+S_{n}}, K v=\frac{S-O_{d}-S_{n}}{S}$

The loss indicator $(M s)$ concerning materials in connection with mechanical wear is calculated as follows [3]:

$$
M s=\frac{O_{d}}{S} \cdot 100 \%
$$

As regards machining, apart from the loss indicator the percentage of economic efficiency related to waste reduction is also specified:

$$
H_{s}=\frac{\left(M s_{0}-M s_{1}\right) \% \cdot \mathrm{S}_{1}}{100}
$$

where:

$H_{s}=$ Percentage of economic efficiency concerning waste reduction;

$M s_{0}$ and $M s_{1}=$ Classes of wastes generated from materials in the basic or recorded period (\%);

$S_{I}=$ Total consumption of materials related to machining; [3]

\subsubsection{Consumption Standard}

The average standard of consumption and average percentage of material consumption for the identical kinds of products are specified as per the following formula [3]: 


$$
N_{s}=\frac{\sum n_{i} q_{1}}{q_{1}}, N s_{p}=\frac{\sum n_{1} q_{1}}{q_{1}}
$$

where:

$N_{s}=$ Average standard of consumption;

$N_{s p}=$ Average percentage of consumption;

$n_{i}$ a $n_{1}=$ Individual standard and ratio of consumption of monitored materials for different products of the same type;

$q_{1}=$ Amount of products of each kind produced in the period monitored;

The average percentage of consumption standard reduction is expressed as follows:

$$
N_{z}=\frac{\sum n_{i 1} \cdot \mathrm{q}_{\mathrm{p}} \cdot 100}{\sum n_{i 0} \cdot \mathrm{q}_{\mathrm{p}}}-100 \%
$$

where:

$N_{z}=$ Percentage of consumption standard reduction;

$n_{i 0}=$ Standards of material consumption in relation to different types of products produced in the preceding period;

$n_{i 1}=$ Standards of material consumption in relation to different types of products produced in the monitored period;

$q_{p}=$ Planned amount of products per each type in the period monitored; [3]

The index of consumption standard fulfilment $\left(i_{n}\right)$ for several types of production is calculated as follows:

$$
i_{n}=\frac{\sum n_{1} \cdot \mathrm{q}_{1}}{\sum n_{1} \mathrm{q}_{1}}
$$

where:

$\sum \mathrm{n}_{1} \mathrm{q}_{1}-\sum \mathrm{n}_{\mathrm{i}} \mathrm{q}_{1}=$ Specifies the economic (+) or excessive (-) consumption of materials in the period monitored;

$q_{1}=$ Manufactured amount of products of each kind in the period monitored; [3]

\subsubsection{Material Substitution}

Released materials represent a large amount of scarce material released due to its substitution by some other material. The amount is determined as follows [3]:

$$
M_{1}=\sum q_{1} n_{i}, \quad \text { or } \quad M_{1}=\sum q_{1} n_{1}
$$

where:

$M_{1}=$ Volume of released scarce materials;

$n_{i}$ a $n_{1}=$ Consumption standard and percentage of consumption of scarce materials per unit of specified production types;

$q_{1}=$ Total amount of products of each kind manufactured from substituting materials;
When substituting material in an enterprise savings are created thanks to the use of substituting materials calculated through the following formula:

$$
H_{p o}=\sum q_{1}\left(N_{s n} \cdot \mathrm{VC}_{\mathrm{n}}+\mathrm{S}_{\mathrm{n}}\right)-\sum q_{1}\left(N_{s v} \cdot \mathrm{VC}_{\mathrm{v}}+\mathrm{S}_{\mathrm{v}}\right)
$$

where:

$H_{p o}=$ Economic efficiency on the corporate level;

$N_{s n}=$ Consumption standard of substituting materials;

$N_{s v}=$ Consumption standard of substituted materials;

$V C_{n}=$ Wholesale price of substituting materials;

$V C_{v}=$ Wholesale price of substituted materials;

$S_{n}=$ Value of products manufactured from substituting materials;

$S_{v}=$ Value of products manufactured from substituted materials;

The economic efficiency concerning the utilisation of substituting materials $\left(H_{n h}\right)$ of different products can be, from the financial point of view, calculated upon the consideration of the length of such product use by consumers, e.g.:

$$
H_{n h}=\sum q_{1}\left(N_{s n} \cdot \mathrm{VC}_{\mathrm{h}}+\mathrm{S}_{\mathrm{n}}\right)-\sum q_{1}\left(N_{s v} \cdot \mathrm{VC}_{\mathrm{v}}+\mathrm{S}_{\mathrm{v}} \frac{t_{n}}{t_{v}}\right)
$$

where:

$t_{n}=$ Length of the use of products manufactured from substituting materials;

$t_{v}=$ Length of the use of products manufactured from substituted materials;

The calculation of efficiency of material substitution shows how much more efficient is to use substituting materials for manufacturing purposes compared to initial materials:

$$
K_{e}=\frac{n_{v}}{n_{n}} \cdot \frac{\mathrm{C}_{\mathrm{v}}}{\mathrm{C}_{\mathrm{n}}} \cdot \frac{\mathrm{K}_{\mathrm{n}}}{\mathrm{K}_{\mathrm{v}}} \cdot \frac{\mathrm{t}_{\mathrm{n}}}{\mathrm{t}_{\mathrm{v}}}
$$

where:

$K_{e}=$ Coefficient of substitution efficiency;

$n_{n} a n_{v}=$ Consumption standards concerning substituting and substituted materials;

$K_{n} a K_{v}=$ Coefficient of the use of substituting and substituted materials in manufacturing process; [3]

\subsubsection{Warehouse Management}

The warehouse turnover time of materials $\left(O_{d}\right)$ is calculated using an average stock balance $\left(Z_{l}\right)$, number of days in the period monitored $(d)$ and turnover of such warehouse $\left(O_{s}\right)$ using the following formula: [3]

$$
O_{d}=\frac{Z_{1} \cdot \mathrm{d}}{\mathrm{O}_{\mathrm{s}}}
$$

The stock turnover is a sum of materials taken from a warehouse and materials issued from such warehouse.

The rate of stock turnover $\left(O_{r}\right)$ is calculated as: 


$$
O_{r}=\frac{O_{s}}{Z_{1}}, \text { or } O_{r}=\frac{d}{O_{d}}
$$

Table 1 Comparison of the advantages and disadvantages of stockholding

\begin{tabular}{|c|c|c|}
\hline & Advantages & Disadvantages \\
\hline $\begin{array}{l}\text { Input } \\
\text { stock }\end{array}$ & $\begin{array}{l}\text { - Generating strategic } \\
\text { inventories used in the } \\
\text { case of late deliveries } \\
\text { - Using bulk } \\
\text { discounts/rebates } \\
\text { - Rational investment } \\
\text { should price increase } \\
\text { be expected }\end{array}$ & \multirow{3}{*}{$\begin{array}{l}\text { - Unnecessary costs } \\
\text { related to stock } \\
\text { maintenance } \\
\text { - Capital tied up in } \\
\text { inventories } \\
\text { - Increase in stock costs } \\
\text { reduces the return on } \\
\text { investment } \\
\text { - Inventories reduce } \\
\text { corporate liquidity } \\
\text { - Risk of deterioration } \\
\text { or obsolescence }\end{array}$} \\
\hline $\begin{array}{c}\text { Work-in- } \\
\text { process } \\
\text { stock }\end{array}$ & $\begin{array}{l}\text { - Effective use of } \\
\text { capacities in } \\
\text { production } \\
\text { - Better flexibility } \\
\text { related to production } \\
\text { scheduling } \\
\text { - Removal of } \\
\text { irregularities related to } \\
\text { corporate plan } \\
\text { fulfilment }\end{array}$ & \\
\hline $\begin{array}{l}\text { Finished } \\
\text { product } \\
\text { stock }\end{array}$ & 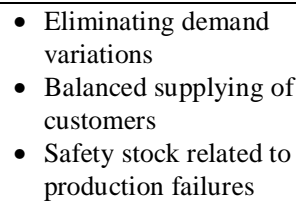 & \\
\hline
\end{tabular}

The stock turnover in the period monitored is calculated as:

$$
O_{r p}=\frac{M_{p}}{\overline{Z_{p}}}, \text { or } O_{r s}=\frac{M_{s}}{\overline{Z_{s}}}
$$

where:

$O_{r p}$ and $O_{r s}=$ Planned and actual number of turnovers in the period monitored;

$M_{p}$ and $M_{s}=$ Planned and actual volume of production from warehouses in the period monitored; $\overline{Z_{p}}$ and $\overline{Z_{s}}=$ Planned and actual average product stock balance;

A relative increase or decrease of actual average stock $\left(Z_{r}\right)$ caused by faster or slower turnovers of stock compared to the planned turnover is calculated as a difference between the average actual and average planned stock using the following formula [3]:

$$
\mathrm{Z}_{\mathrm{r}}-\overline{Z_{p}} \text {, and } Z_{r}=\frac{M_{s}}{O_{r p}}
$$

\subsubsection{Warehouse Performance/Outputs}

The indicator of stock keeper's performance is expressed as:

$$
v=\frac{O}{P} \text { or } v=\frac{M}{P}
$$

where:

$v=$ Performance of a single worker in a warehouse;

$O=$ Total turnover from implementation,

$P=$ Average number of employees working in a warehouse;

$M=$ Total number of unloading and loading jobs in a warehouse; [3]

The coefficient of $\left(K_{m}\right)$ stock work mechanisation is expressed by the following formula:

$$
K_{m}=\frac{M_{m}}{M}
$$

where:

Mm= Volume of stock handling jobs carried out using machines [3].

\subsection{Defining the Structure and Level of Sales Stock}

In last few years, the way inventories are looked at has changed substantially. They are no longer the first alternative to use when trying to ensure the flexibility in production. Currently, they are seen as the last resort for enterprises.

\subsubsection{Effective Level of Sales Stock}

The effective level of sales stock specifies the amount of finished products and the number of days, for which such finished products are stored in corporate sales warehouses from the moment of their takeover from production to the moment of their dispatch to customers. It is determined by [3]:

- The technical and economic calculation of basic elements forming stock;

- The use of warehouse statistic data for the period preceding the given period;

The statistical approach concerning the effective level of sales stock specification is determined on the basis of records from years preceding the given year.

Calculation-based method of sales stock standardisation

The volume of sales stock expressed in physical units is influenced by an average daily movement of products from production to sales warehouses $(M)$ and by the time of such product storage $\left(C_{s}\right)$ [3].

a) In the case of continuous production and continuous product supply to sales warehouses:

$$
N_{s}=M \cdot \mathrm{C}_{\mathrm{s}}
$$

b) In the case of production characterised by irregular product supply to sales warehouses with the interval of several supplies per month [3]: 


$$
N_{n}=\frac{M_{p} \cdot \mathrm{C}_{\mathrm{s}}}{\mathrm{D}}
$$

where:

Ns = Effective level of sales stock;

$N n=$ Effective level of stock with irregular product supply to warehouses;

$M p=$ Average amount of products handed over to sales warehouses;

$D=$ Number of work days in a month;

b) The effective stock level expressed in days is calculated based on the following formula: [3]

$$
N_{d}=\frac{N_{s} \cdot \mathrm{D}}{\mathrm{Z}_{\mathrm{z}}+\mathrm{P}_{\mathrm{v}}+\mathrm{Z}_{\mathrm{k}}} \text { or } N_{d}=\frac{N_{s}}{\mathrm{M}_{\mathrm{e}}}
$$

where:

$N_{d}=$ Effective level of sales stock expressed in days;

$N_{s}=$ Effective level of sales stock expressed in physical units;

$\mathrm{P}_{\mathrm{v}}=$ Average number of products handed over to sales warehouses:

$Z_{z}=$ Sales stock in warehouses at the beginning of a month;

$Z_{k}=$ Sales stock in warehouses at the end of a month;

$M_{e}=$ Average amount of products dispatched to customers each day;

Value-based effective level of sales stock [3]:

$$
N_{h}=N_{f} \cdot \mathrm{VC}
$$

where:

$N_{h}=$ Value-based effective level of sales stock;

$N f=$ Effective stock level expressed in physical units;

$V C=$ Wholesale price;

The duration of product storage in sales warehouses $\left(C_{s}\right)$ depends on many factors. Following the receipt of such products in warehouses it is necessary to divide them based on their types and store them in a relevant place in a warehouse [3].

The time necessary for the performance of these storage operations $\left(C_{o}\right)$ is calculated as the sum of all time period necessary for individual operation performance:

$$
C_{o}=C_{1}+C_{2}+C_{3}+\ldots+C_{i}
$$

where:

$C_{1,2,3, \ldots i}=$ time periods necessary for each operation performance; [3]

The time necessary for product treatment $\left(C_{u}\right)$ in sales warehouses can be specified as follows:

$$
C_{u}=\sum \frac{M_{s}}{N_{r} \cdot \mathrm{P}_{\mathrm{r}}} \quad \text { or } \quad C_{u}=\sum \frac{M_{s} \cdot \mathrm{N}_{\mathrm{u}}}{\mathrm{P}_{\mathrm{r}}}
$$

where:

$M_{s}=$ Amount of products to be treated in a single operation;

$N_{r}=$ Effective performance of a single employee per given operation and per shift;

$P_{r}=$ Number of employees carrying out this operation per shift;

$N_{u}=$ Effective time period necessary for single product treatment; [3]

\subsubsection{Sales Stock Balance}

At the end of each period actual and planned balances of sales stock are specified by the following relation [3]:

$$
\begin{aligned}
& Z_{p k}=Z_{s z}+V_{p}-D_{p} \\
& Z_{s k}=Z_{s z}+V_{s}-D_{s}
\end{aligned}
$$

where:

$Z_{p k}=$ Planned balances of sales stock at the end of the period monitored;

$Z_{s k}=$ Actual balances of sales stock at the end of the period monitored;

$Z_{s z}=$ Actual balances of sales stock at the beginning of the period monitored;

$V_{p}=$ Planned production in the period monitored;

$V_{s}=$ Actual production in the period monitored;

$D_{p}=$ Planned product deliveries;

$D_{s}=$ Actual product deliveries;

The fulfilment of delivery plans is mainly influenced by the following three factors:

- Production plan fulfilment;

- Mobilisation of finished product stock;

- Transportation activities;

The percentage of their individual impact is specified in amounts and percentage and shows exceeded or not fulfilled delivery plans [3].

a) Production plan fulfilment

$$
\begin{aligned}
& V_{v m}=V_{s}-V_{p}(\mathrm{MJ}) \\
& V_{v c}=\frac{\left(V_{s}-V_{p}\right) 100}{D_{p}}(\%)
\end{aligned}
$$

where:

$V_{v m}=$ Influence of production expressed as the number of products delivered;

$V_{v c}=$ Influence of production expressed as the percentage of products delivered;

$V_{s}=$ Actual number of manufactured products in the period monitored; 
$V_{p}=$ Planned number of products to manufacture in the period monitored; [3]

b) Mobilisation of finished product stock

$$
\begin{aligned}
& V_{z m}=Z_{p k}-Z_{s k}(\mathrm{MJ}) \\
& V_{z c}=\frac{\left(Z_{p k}-Z_{s k}\right) \cdot 100}{D_{p}}(\%)
\end{aligned}
$$

where:

$V_{z m}=$ Influence of the mobilisation of delivered product stock expressed in mass units;

$V_{z c}=$ Influence of the mobilisation of delivered products expressed as percentage;

$Z_{p k}=$ Planned stock at the end of the period monitored, $Z_{s k}=$ Actual stock at the end of the period monitored; [3]

c) Transportation activities

$$
\begin{aligned}
& V_{d m}=D_{z s}-D_{s}(\mathrm{MJ}) \\
& V_{d c}=\frac{\left(D_{z s}-D_{s}\right) \cdot 100}{D_{p}}(\%)
\end{aligned}
$$

where:

$V_{d m}=$ Influence of transportation expressed in mass units; $V_{d c}=$ Influence of transportation expressed as percentage; $D_{z s}=$ Actual source of deliveries calculated as follows [3]:

$$
D_{z s}=V_{s}+\left(Z_{s z}-Z_{s k}\right)
$$

\section{Conclusions}

The theory of inventory management provides a wide range of management costs support and therefore it creates an important part of the analysis of logistics systems of companies in the market environment. Effective management of stocks, despite of extensive theoretical modelling techniques, is limited by a number of problems in specific conditions, which should be constantly solved by a management of particular companies. The easiest way is to manage stocks in an enterprise, which sale is not a subject of a strong seasonal influences over a longer period of time. Inventory management is an important factor to achieve better business performance. Inappropriate inventory levels are causing problems, the worst of which is the creation of excessive costs. In addition, overstocks bind a capital that could be used to finance other business needs, reducing stocks can increase productivity, but their lack may lead to the loss on the company's performance. Thus, the current trend is a large, or complete elimination of stocks.

\section{Acknowledgments}

The research was carried out as part of VEGA project No. 1/0216/13 „Methods and new approaches study to measurement, evaluation and diagnostic performance of business processes in the context of logistics management company. "and the solution of the VEGA No. 1/0036/12 project named „Methods development and new approaches to design of input, interoperable and output warehouses and their location in mining, metallurgy and building industries".

\section{References}

[1] BIGOŠ, P., KISS, I., RITÓK, J., KASTELOVIČ, E.: Materials flows and logistics II., Materiálové toky a logistika II., Košice: Elfa, 2008. (Original in Slovak)

[2] EMMETT, S.: Management of supplies, Rízení zásob, Brno: Computer Press a.s., 2008. (Original in Czech)

[3] HORČIAK, J.: Deliver-customer relationships in industry, Dodávatel'sko-odberatel'ské vzt'ahy v priemysle, Bratislava, 1983. (Original in Slovak)

[4] LAMBERT, D., STOCK, J.R., ELLRAM, L.: Logistics, Logistika. Brno: CP Books a.s., 2005. (Original in Czech)

[5] MALINDŽÁK, D. et al.: Aplication of modeling and simulation in company logistics, Aplikácia modelovania a simulácie v logistike podniku, Košice: TU, FBERG, p. 286, 2009. (Original in Slovak)

[6] MALINDŽÁK, D. et al.: Modelling and simulation in logistics (theory of modeling and simulation), Modelovanie a simulácia v logistike (teória modelovania a simulácie), 1. edit., Košice: TU, p. 182, 2009. (Original in Slovak)

[7] ROSOVÁ, A.: Purchasing and supplying logistics, Logistika nákupu a zásobovania, Košice: Dekanát Edičné stredisko, 2011. (Original in Slovak)

[8] ROSOVÁ, A.: Logistics of firm supply with application of alfa-omega matrx, Logistika zásobovania firmy s aplikáciou alfa-omega matice. In: Strojárstvo. Vol. 11, No. 7-8 (2007), p. 83/13-85/15, (2007). (Original in Slovak)

[9] SANIUK, A., SANIUK, S.: Application of the theory of constraints for resource management of micro and small enterprises, Zastosowanie teorii ograniczeń w zarządzaniu zasobami mikro i małych przedsiębiorstw, 355-363, Zeszyty Naukowe Uniwersytetu Szczecińskiego, 2010. (Original in Polish)

[10] SANIUK, A., SANIUK, S., WITKOWSKI, K.: Using Activity Based Costing in the metalworking processes, METAL 2011, TANGER, 2011.

[11] SCHULTE, G.: Logistics, Logistika, 1. edit., Praha, Victoria Publishing, p. 301, 1994. (Original in Czech)

[12] STRAKA, M.: Logistics of distribution, How effectively put product into the market, 1st edition, Bratislava, EPOS, p. 400, 2013. (Original in Slovak) 
[13] VIESTOVÁ, K. et al.: Lexicon of logistics, Lexikón logistiky, 2nd edit., Bratislava: Iura Edition, p. 204, 2007. (Original in Slovak)

\section{Review process}

Single-blind peer reviewed process by two reviewers. 